\title{
Environmental dimensions and features affecting organizational entrepreneurship development in I ranian public hospitals
}

\author{
Amir Ashkan Nasiripour ${ }^{1}$, Pouran Raeissi ${ }^{2}$, Hossein Hosseini-Fahraji ${ }^{1}$ \\ 1. Department of Health Services Management, Science and Research Branch, Islamic Azad University, Tehran, Iran. \\ 2. Department of Health Services Management, School of Management and Medical Information Science, Tehran \\ University of Medical Sciences, Tehran, Iran.
}

Correspondence: Amir Ashkan Nasiripour. Address: Department of Health Services Management, Science and Research Branch, I slamic Azad University, Tehran, Iran. E-mail: nasiripour@srbiau.ac.ir

Received: January 29, 2012

Accepted: October 16, 2012

Online Published: December 9, 2012

DOI : $10.5430 /$ jha.v2n1p88

URL: http://dx.doi.org/10.5430/jha.v2n1p88

\section{Abstract}

One of the important issue regarding the study of change in the organizations is "organization's environment"; the territory in which an organization form and change during its life cycle. Among other factors, environmental dimensions and features are the important indices being used to estimate and understand the environment surrounding an organization. The main purpose of the present study was to identify the effective environmental factors (dimensions and features) on the organizational entrepreneurship in the Iranian Public hospitals. The sample contained 500 operating managers, supervisors, head nurses, nurses and head officers various affairs offices in hospitals such as affirmative action office and so on. A stratified random sampling technique was utilized to select the sample. The criteria for selection of the subjects were having at least a bachelor's degree, and three years of working experience. The data was collected via a self-report questionnaire. The exploratory and confirmatory factor analyses were used to identify the environmental factors affecting organizational entrepreneurship's development in the Iranian public hospitals. The amount of KMO of environmental features was $83 \%$, with $p$-value less than 0.05 . The extracted factors explained 89 percent of the variance of environmental factors affecting organizational entrepreneurship's development in the Iranian public hospitals.

The amounts of CFI, NFI, RFI and IFI for the fitted model were all above 0.99 , GFI was 0.99 , and RMSEA was 0.05 which all verified impact of environmental factor effect on the organizational entrepreneurship. The dimensions such as dynamism, complexity, munificence, struggle and their features in were observed in the external environment of Iran public hospitals, and they had direct and significant effect on organizational entrepreneurship. Therefore, the existing circumstances in the external environment of the stated hospital are ready for persuading, and generating motivation in employees and also leading hospital toward entrepreneurial action to encounter the existing challenges.

\section{Key words}

Entrepreneurship, Organization, Entrepreneurship, External environment, Hospital

\section{I ntroduction}

Environment includes all factors outside the territory and boundaries of an organization which are potentially effective on the organization. Each organization should choose a territory in pre-activity stage and also in development process. As 
organizations studying market and costumers' need use market and environment facilities after necessary recognitions, territory is significant in organization environment issues. Therefore, territory of an organization is choosing fields appropriate to organization activity regarding environment ${ }^{[1]}$. Naman and Slevin introduced organization business environment as a set of all physical and social components that are considered directly in all behavior and decision-making of the organization members ${ }^{[2]}$.

In the past decades development and competition among business modules has caught the attention of many researchers to study environment and its impact on the organizational features. This has been mainly due to the priority of phenomena such as business confine globalization, fast-pace technology growth, products' lifetime decline, and variation in costumers' requirements overtime. The focus of scientists and researchers on environment impacts on the organizational features such as structure or performance reflects the significance of this issue in organizational literature. They have studied the relationship between organization environment and structural features, or the relationship between environmental dimensions and organization performance ${ }^{[3-11]}$.

Today, in health care organizations especially the public hospitals, numerous direct and indirect services are offered to the clients (i.e. patients, their families, and students), and these services are done through separate, but in line processes, therefore, these organizations are led to their missions and objectives which includes health, education and research services to the society. It is clear that the number, and type of services should be upgraded, removed or replaced according to the environmental changes, this is because of increase in the number of patients, needs and expectations of target groups, dramatic changes in type and severity of disease (change in disease pattern) due to changes in life style, increase in life expectancy, increasing number of medical graduates, devising and implementing new technologies, and the most important factor is to increase the customer satisfaction, and other stakeholders. Responding to such escalating need is not possible, but through innovation, and entrepreneurship in these organizations. However, despite the fact that most of Iranian politicians and health care managers are aware of such burning need in this society, and are pointing out the importance and necessity of entrepreneurship for the organization such as hospitals, yet little attention has been paid to this issue so far, and there are so many obstacles on the way ${ }^{[12,13]}$.

Shortell and kaluzny ${ }^{[12]}$ presented environmental parameters effecting managers performance and delivering health care services. These factors include: environmental resources, payment by performance, new technologies advancement, population aging, increasing cultural and ethnic variety of population, and changes in supplying and training health experts, change in diseases patterns, information, manufacturing, management, and globalization. They believe that organizations success solution is a proper concept of external environment, because each of these factors results in out-breaking of attitudes, ideas, skills, behaviors, and new way of thinking.

Many Pioneer organizations in business, have overcame the environmental challenges with the help of development and deployment of strategies based on entrepreneurial activities. A closer look at the definition of entrepreneurship will make the relationship of entrepreneurship, and environment phenomena clear. The concepts of "value", "source" and "opportunities" in entrepreneurship definitions, all have roots in environment, therefore, the effectiveness of value creation, identification, providing the right opportunity, and source proper identification; all requires a full understanding of the relationship between entrepreneurial behaviour and the environment ${ }^{[14-16]}$.

Moghimi ${ }^{[17]}$ believes that one way to deal with proliferation of environmental challenges facing organizations is to enhance the output level of innovative and entrepreneurial ideas. The viable statistics reveals that organizational entrepreneurship is one of the most efficient ways to respond to environmental fluctuations.

Organizational entrepreneurship is a system that has increased the Innovative capacity of managers and work forces in the organization and has made it operational. This system encourages them to determine, and achieve their entrepreneurial goals by developing the areas and organizational units, and also developing the products and services. It will define the sources, make it operational and will find the best suppliers and clients inside and outside of the organization to achieve its 
goals and production. Aspects of organizational entrepreneurship involve innovation, rebuilding, pioneering, and new risky actions that are used to measure organizational entrepreneurship ${ }^{[18]}$.

In order to investigate the organizational environment impact on organizational performance, past researchers have looked at various dimensions such as munificence, dynamism, complexity, instability, heterogeneity, confusion, which have also been named differently by different researchers ${ }^{[19-22]}$. Aldrich ${ }^{[23]}$ in his book entitled "Organization and environment" introduces five environmental aspects, while other researchers ${ }^{[24,25]}$ have reduced them into three (such munificence, dynamics and complexity) by combining the stated aspects.

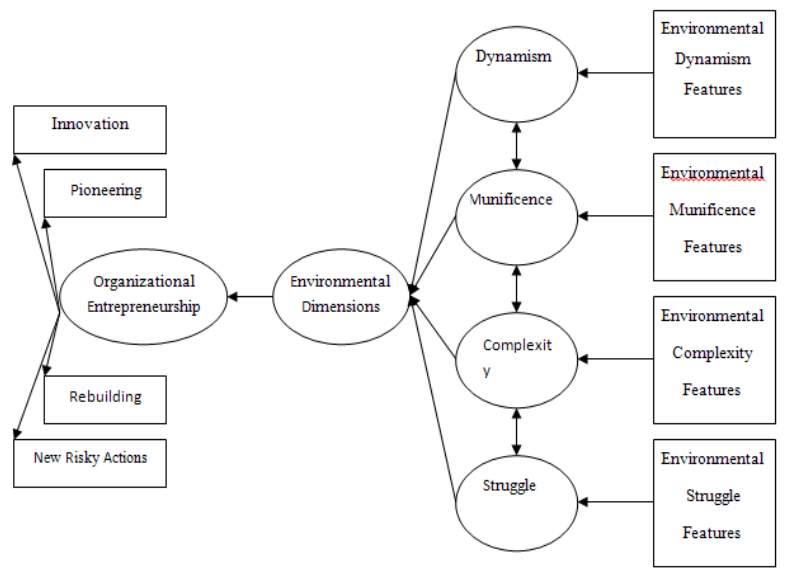

Figure 1. The Conceptual Model of this Research

In this study, we looked at those environmental dimensions which were more commonly used by different researchers, and scholars. These dimensions are dynamism, munificence (resources availability), complexity, which each of them have their own components. Figure 1 represents the conceptual model of this research.

"Environmental struggle" Indicates the degree that environment is regarded as a direct threat for the environment. A struggle which is formed by factors such as industry hazardous configuration, intense competition, stressful business and relative lack of business opportunities. Environmental struggle are because of undesirable changes in the market due to business globalization, increasing number of competitors, changing the ways that companies create a position in market for themselves, undesirable changes in legislation and increasing protectionist policies of some companies ${ }^{[14,15,26,27]}$.

"Environmental munificence" is defined as the level of providing adequate resources from environment to support the existing or emerging organization ${ }^{[22,28]}$. Environmental munificence is the availability of environmental resources for companies-Resources that organizations often compete in order to control them ${ }^{[29]}$.

"Environmental Dynamism" is ruling when customer and competitors prediction is more difficult and market trend change rate and industrial innovations are increased. In such condition, obvious changes have occurred in demand and the level of environmental opportunities has also increased ${ }^{[30,31]}$. A related research in this area is a study done by Zahra (1993) which is about the relationship between entrepreneurship and firm performance in environmental Dynamism conditions. Results of this research showed a positive relationship between entrepreneurship and performance in environmental Dynamism conditions and also showed a negative relationship between these two concepts in a static environment ${ }^{[32]}$. In a similar study Miller ${ }^{[33]}$ found that in unstable environmental conditions (Dynamism and unpredictable environment), using innovative strategies will increase the functional output level. Wiklund and Shepherd ${ }^{[34]}$ also conducted a research on small firms and found out that environmental Dynamism will moderators the 
firm performance and entrepreneurial tendencies, and the relationship between these two variables is more significant as the environmental Dynamism increases.

Some researchers believe that "Environmental complexity" is a criterion for determining homogeneity or diversity. Complexity is the result of several factors on the organization which can be affected simultaneously ${ }^{[35]}$. Complexity of the business environment is the major source and factor of environmental fluctuations. This complexity may be due to the increase in the number of organizations in an innovative industry, frequency of enterprise components, Changes in the disease patterns, diversity of different groups of customers' needs, Changes in stakeholder's expectations ${ }^{[12,25,36,37]}$.

To confirm the conceptual model of environment effect on Organizational entrepreneurship an exploratory factor analysis and, confirmatory factor analysis (structural equation modeling technique) were used.

In this research it is tried to identify effective environmental dimensions and features on the entrepreneurship in Iranian public hospitals. This study also provides and measures the environmental conditions of the Iranian public hospitals to stimulate their entrepreneurial enterprise and entrepreneurship.

The goal of the present study was to present a model of effective Environmental dimensions and features on Organizational entrepreneurship development in Iranian public hospitals.

\section{Methodology}

The research environment, are twelve hospitals (from five Universities of Medical Sciences) which that have been introduced as excellence poles by the Supreme Council of Medical Sciences in the Iranian Ministry of Health.

The statistical population of this study consisted of operating managers and experts from hospitals, who had full knowledge about the hospital internal and external environment, they had a significant role in servicing the patients and were influential in the development of Organizational entrepreneurship and they did not regard their own organizational benefits (in this study). These individuals must have bachelor or higher degree and at least three years' work experience. In the studied hospitals, people who have these features are nurses, head nurses, supervisors and experts of affirmative affaires. So the qualified populations were identified to 4,200 patients.

The Stratified Random Sampling method is used in this research. They were divided to for above groups, who were categorized according to the ratio of volume of each class, with the base of sample size.

Using a sample size formula for Cochran and considering the volume of people $(4,200)$ and, $(P=0.5),(Q=0.5),(D=0.05)$ and $(T=1.96)$, sample size in this study were determined 352. But, with a conservative approach and to ensure more and also according to Momeni and, Faal-e-qayumi ${ }^{[38]}$ that for structural equation modeling, 10 to 20 samples should be estimated for each parameter, 500 samples were considered according to the number of questions in the questionnaire.

The inductive study, library research is used to gather the required data. This method is used for identification of models, theories, frameworks, and also similar studies in the field of organizational entrepreneurship. The result of this study was the effect of environmental components output on organizational entrepreneurship.

In order to collect data related to the environmental component, an standard questionnaire was used, which have been used in numerous studies by researchers in the field of entrepreneurship such as Lumpkin., et al; Zahra et al,; Lumpkin and Dess and Morris and Kuratko ${ }^{[39-42]}$. The questionnaire included 24 questions with Likert five-choice test (very low, low, medium, high, and very high) were valued from 1 to 5. 
In collecting data related to organizational entrepreneurship, standard questionnaires, which many researches have been done in the field of entrepreneurship by them, were used. Thus combination tool was used. These tools include the required components. Lampkin, Zoren, Antonić, and Hisrich scales are also a combination of components of other researchers ${ }^{[12,25,30,40,43-51]}$. This questionnaire includes 17 questions, which measured the dimensions of organizational entrepreneurship (innovation, rebuilding, pioneering, and new risky actions) and were valued from 1 to 5 by the Likert five-choice test (very low, low, medium, high, and very high).

The questionnaire validity of this study was assessed by Faced Validity (expert opinions). Therefore, the comments of 15 health management professors and hospital Executives who were participating in the field of entrepreneurial activity were used. Structural validity of the survey instruments were tested using factor analysis.

Reliability of the questionnaire for this study was assessed by distributing them among 30 people from the target group and its redistribution after 10 days and then the Cronbach's alpha coefficient were calculated and the correlation between these responses was $90 \%$.

Data analysis was performed using factor analysis, regression, path analysis and model fitting tests. LISREL and SPSS software was used to for data analysis.

\section{Results}

Table 1. Demographic Information for the Investigated Subjects

\begin{tabular}{llll}
\hline Variables & Categories & $\mathbf{N}$ & \% \\
\hline \multirow{4}{*}{ Age } & $20-29$ & 113 & 23.3 \\
& $30-39$ & 185 & 38.1 \\
& $40-49$ & 160 & 33 \\
Gender & $50-59$ & 27 & 5.6 \\
& More than 60 & 0 & 0 \\
Marital status & male & 61 & 12.6 \\
& female & 424 & 87.4 \\
Position & single & 118 & 24.3 \\
& married & 367 & 75.7 \\
& supervisor & 31 & 6.4 \\
& Head-nurse & 56 & 11.5 \\
Education & nurse & 359 & 74 \\
& Official & 39 & 8 \\
& B.A. & 463 & 95.5 \\
Job experiences & M.A. & 22 & 4.5 \\
(year) & PhD & 0 & 0 \\
& $3-4$ & 123 & 25.4 \\
& $5-9$ & 101 & 20.8 \\
& $10-14$ & 137 & 28.2 \\
& $15-19$ & 66 & 13.6 \\
& $20-24$ & 53 & $10-19$ \\
\hline
\end{tabular}


The findings revealed that $12.6 \%$ of the employees were male and $87.4 \%$ female where $70.1 \%$ of them were falling between 30 to 49 years old. About $75.7 \%$ of the participants were married, $95.5 \%$ had a B.S degree, $74 \%$ were nurse, and $28.2 \%$ had 10-14 years of working experience (see Table 1).

Table 2. Mean and T- test results on the Environmental Dimensions

\begin{tabular}{llllll}
\hline $\begin{array}{l}\text { Environmental } \\
\text { dimensions }\end{array}$ & Mean & $\begin{array}{l}\text { Standard } \\
\text { deviation }\end{array}$ & $\begin{array}{l}\boldsymbol{T} \text { - test } \\
\text { Statistic }\end{array}$ & $\begin{array}{l}\text { Mean } \\
\text { difference }\end{array}$ & $\boldsymbol{p}$ \\
\hline Dynamism & 3.5075 & .65895 & 16.961 & .50751 & .000 \\
Munificence & 3.6387 & 1.43046 & 9.833 & .63866 & .000 \\
Complexity & 3.5993 & .70519 & 18.716 & .59931 & .000 \\
Struggle & 3.5027 & .68337 & 16.200 & .50268 & .000 \\
\hline
\end{tabular}

In order to understand the current state of entrepreneurship environmental components and its position in Iranian public hospitals, the community- average test and student-t was used.

Table 3. Bartlett's test Results, KMO values, total variance being explained by each Environmental Dimensions

\begin{tabular}{llllllll}
\hline \multirow{2}{*}{ Environmental Dimensions } & Value & \multicolumn{2}{c}{ Bartlett's test } & & \multicolumn{2}{c}{ Total variance } \\
& KMO & $\chi^{\mathbf{2}}$ & df & $\boldsymbol{p}$ & & \% of Variance & $\boldsymbol{\lambda}$ \\
\hline Dynamism & .91 & 3195.065 & 21 & .000 & & 71.464 & 5.002 \\
Munificence & .67 & 611.092 & 6 & .000 & & 47.674 & 1.907 \\
Complexity & .74 & 840.667 & 3 & .000 & & 73.104 & 2.193 \\
Struggle & .92 & 4861.838 & 45 & .000 & & 69.622 & 6.962 \\
\hline
\end{tabular}

In this test, the access components average to resources was 3.637 greater than the other components, and then the complexity, dynamics, and the struggle were there.

Table 4. Path Directions in the Model and Standard Estimate of Path Coefficients

\begin{tabular}{|c|c|c|c|c|}
\hline Dimensions & $\begin{array}{l}\text { Path } \\
\text { Direction }\end{array}$ & Dimensions & Standard Estimate of path Beta & $p$ \\
\hline Munificence & $<-\rightarrow$ & Dynamism & 0.78 & .000 \\
\hline Complexity & $<-\rightarrow$ & Dynamism & 0.87 & .000 \\
\hline Struggle & $<-\rightarrow$ & Dynamism & 0.93 & .000 \\
\hline Complexity & $<-\rightarrow$ & struggle & 0.87 & .000 \\
\hline Munificence & $<-\rightarrow$ & struggle & 0.77 & .000 \\
\hline Munificence & $<_{-} \rightarrow$ & complexity & 0.72 & .000 \\
\hline
\end{tabular}


According to the average different values, all the environmental components have positive values. So we can infer that the average of all environmental components in Iran public hospitals is over the average value. In Table 2, Results of $t$ test and the average test show the community at $95 \%$ confidence interval.

In confirmation findings the Exploratory factor analysis of the effective environmental component on organizational entrepreneurship, Dynamism and struggle environmental components with the amount of sampling adequacy (KMO) 0.92 and 0.91 , respectively, are the highest environmental complexity component and munificence environmental components also with 0.74 and 0.67 , is in the next level.

Considering the total variance and Bartlett's test coverage, they show the suitability of this component data for factor analysis and the suitability of components classification. In other words, it shows justified use of factor analysis based on the correlation matrix, which is present in the studied and it has the ability to generalize this value to statistical community (see Table 3).

To provide the Correlation model and its suitable criteria, confirmatory factor analysis, path analysis and structural equation modeling were used. In confirmatory factor analysis, According to the path standard estimates of the $p$-value amount, it was determined that there is a bilateral and significant relationship between environmental aspects. The dimensions of the relationship between environmental dynamism and struggle with the value (0.93) are the highest and between complexity and availability with the value (0.72) is the lowest (see Table 4).

Table 5. Correlation Matrix between the Environmental Aspects of Organizational Entrepreneurship

\begin{tabular}{lllll}
\hline Dimensions & Dynamism & Munificence & Complexity & Struggle \\
\hline Dynamism & 1 & & & \\
Munificence & .681 & 1 & & \\
Complexity & .797 & .664 & 1 & \\
Struggle & .894 & .710 & .799 & 1 \\
\hline
\end{tabular}

Figure 2. The model of relationships between Environmental Dimensions.

DYNY = Dynamism

MUNY = munificence

$\mathrm{CONY}=$ complexity

HOY $=$ struggle

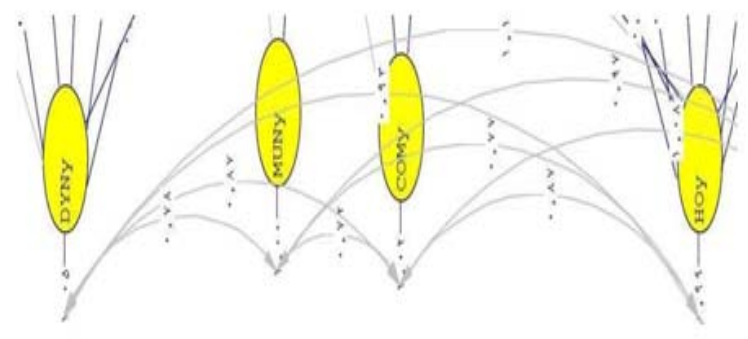

In this study for model fitness, some fitness parameters were used, such as chi-square to degrees of freedom $\left(\chi^{2} / \mathrm{df}\right)$. Experts often consider value less than 3 as fitness of the models. In model of the relationship between the environmental dimensions this value is 2.24 , which confirms the propriety and suitability of the model. When the model adequacy index (CFI, NFI, RFI and IFI) are closer to 1, it indicates a good fit, they are all upper than 0.99, which is a good value. The GFI value of 0.99 was also appropriate. The root mean square error of approximation (RMSEA) is that the closer to zero indicate better fit of the model. It was 0:05 in this model which show a good value. A p-value below 0.05 is also another sign of the occasion (see Figure 2). Table 5 shows the correlation matrix between these dimensions. Therefore, the 
hypothesis that there is a bilateral relationship between effective environmental dimensions in organizational entrepreneurship in public hospitals in Iran was approved.

Exploratory factor analysis about effect of environmental dimensions on organizational entrepreneurship, found out and set the index of sampling adequacy (KMO) and 0 / 83. In Bartlett's test also the chi-square value of about 1644.078 was evaluated as: degree of freedom was 6 and the p-value amount was less than $0 / 05$. These criteria reflect the suitability of the data for environmental components which are extracted from the questionnaire. The classification, with 3.57 total equity covers 89 percent of variance that indicate the suitability of them. In other words, it shows justified use of factor analysis based on the correlation matrix, which is present in the studied and it has the ability to generalize this value to statistical community.

The peripheral component coefficients are respectively: struggle 0.290 , dynamics 0.287 , and complexity 0.276 and resources availability 0.254 . Propriety indicators to confirm the general pattern of environmental aspects and components effect on organizational entrepreneurship in public hospitals in Iran were as follows: Index values for CFI, NFI, RFI and IFI are all over 0.98 , GFI value is 0.72 and RMSEA 0.07 were obtained in this model.

Figure 3. The Model of Environmental Dimensions and Features Influencing Organizational Entrepreneurship in Iranian Public Hospitals.

Dyny =Dynamism; muny = munificence; cony = complexity; hoy

$=$ struggle; Env.c= environmental component; Org. entr:= organizational entrepreneurship; INNOM= Innovation; SRM=

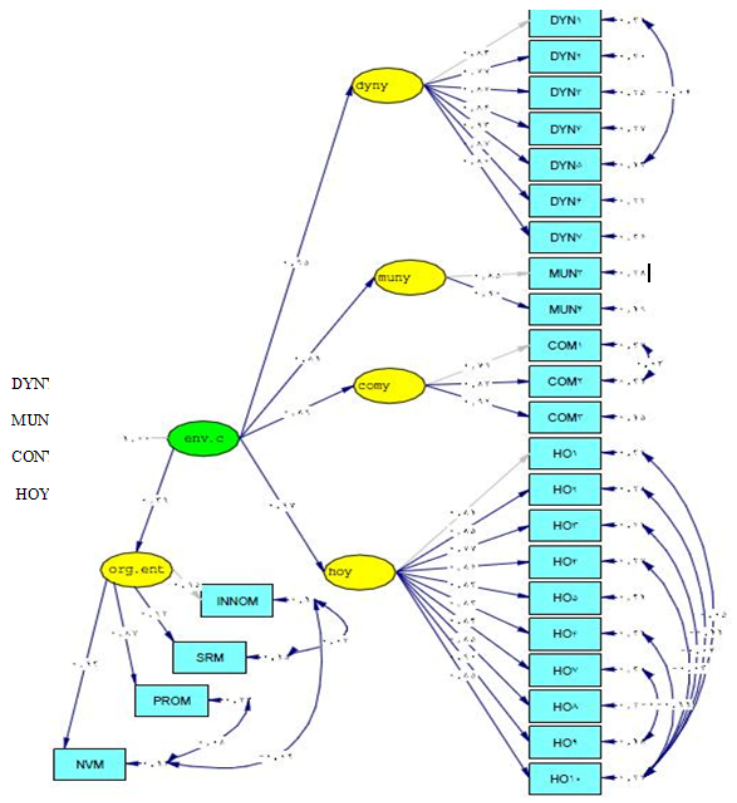

rebuilding; $\mathrm{PROM}=$ pioneering; $\mathrm{NVM}=$ new risky actions

Fitness model values are confirms the organizational entrepreneurial environment. As a result, this model that have been gained through the exploratory factor analysis conducted on the environmental factors and entrepreneurial load factor 0.5 is obtained, is a very good model for examining the relationship between environmental variables and the dependent variable component that is dependent on entrepreneurship. In other words, four verified environmental aspects and their components are of effective environmental structures on organizational entrepreneurial actions in the Iranian public hospitals (Figure 3).

To determine the coefficient of dimensions path and environmental components and also to define the relationship with organizational entrepreneurship, path analysis test was used.

As in Table 6 can be observed with regard to the significance of $T$-Value test, the relationship between size and environmental components of the dependent variable entrepreneurial approval and routes it as the model released are associated. 
Table 6. Obtained Statistics on fitted Model

\begin{tabular}{|c|c|c|c|c|c|}
\hline Dimensions \& Features & $\begin{array}{l}\text { Path } \\
\text { Directions }\end{array}$ & Dimensions & $\begin{array}{l}\text { Standard Estimate } \\
\text { of path's Beta Coefficient }\end{array}$ & $t$ & $p$ \\
\hline Dynamism & $<---$ & environmental & 0.95 & 20.73 & 0.00 \\
\hline Munificence & $<---$ & environmental & 0.81 & 16.9 & 0.00 \\
\hline Complexity & $<---$ & environmental & 0.89 & 18.23 & 0.00 \\
\hline Struggle & $<---$ & environmental & 0.97 & 21.12 & 0.00 \\
\hline Entrepreneurial & $<---$ & environmental & 0.39 & 8.18 & 0.00 \\
\hline Market sharp fluctuations & $<---$ & Dynamism & 0.83 & 22.44 & 0.00 \\
\hline Inconstancy & $<---$ & Dynamism & 0.77 & 20.26 & 0.00 \\
\hline Unpredictable & $<---$ & Dynamism & 0.87 & 24.01 & 0.00 \\
\hline Uncertainty of demand & $<---$ & Dynamism & 0.86 & 23.51 & 0.00 \\
\hline $\begin{array}{l}\text { Uncertainty arising from } \\
\text { technological }\end{array}$ & $<---$ & Dynamism & 0.93 & 22.52 & 0.00 \\
\hline $\begin{array}{l}\text { The rapid advancement of } \\
\text { technology and equipment }\end{array}$ & $<---$ & Dynamism & 0.87 & 22.40 & 0.00 \\
\hline Increase in knowledge (R \& D) & $<---$ & Dynamism & 0.80 & 21.23 & 0.00 \\
\hline Access to resources & $<---$ & munificence & 0.85 & 23.38 & 0.00 \\
\hline Access to Information & $<---$ & munificence & 0.9 & 21.88 & 0.00 \\
\hline Changes in the disease patterns & $<---$ & complexity & 0.8 & 21.23 & 0.00 \\
\hline Frequency of enterprise components & $<---$ & complexity & 0.87 & 21.09 & 0.00 \\
\hline $\begin{array}{l}\text { Changes in stakeholders } \\
\text { expectations }\end{array}$ & $<---$ & complexity & 0.92 & 23.73 & 0.00 \\
\hline High-risk opportunities & $<---$ & struggle & 0.82 & 22.18 & 0.00 \\
\hline Investment areas & $<---$ & struggle & 0.85 & 23.38 & 0.00 \\
\hline Reduction of the service profit & $<---$ & struggle & 0.76 & 19.77 & 0.00 \\
\hline Monopolistic market & $<---$ & struggle & 0.86 & 23.54 & 0.00 \\
\hline Demand reduction & $<---$ & struggle & 0.83 & 22.44 & 0.00 \\
\hline Increased competition & $<---$ & struggle & 0.83 & 22.36 & 0.00 \\
\hline $\begin{array}{l}\text { Standards and regulations } \\
\text { Changes }\end{array}$ & $<---$ & struggle & 0.82 & 22.18 & 0.00 \\
\hline Raw materials quality Changes & $<---$ & struggle & 0.84 & 22.82 & 0.00 \\
\hline Globalization & $<---$ & struggle & 0.89 & 25.22 & 0.00 \\
\hline Costs Increase & $<---$ & struggle & 0.86 & 24.97 & 0.00 \\
\hline
\end{tabular}

According to the current research findings, environmental factors that influence the relationship between four dimensions of the entrepreneurial environment are in order: environmental Struggle 0.97, environmental dynamics 0.95, environmental complexity 0.89 and environmental munificence 0.81 .

The correlation coefficient of environment variable relation to environment on organizational entrepreneurial is 0.39 . So the effect of these components on organizational entrepreneurial is the largest and most effective environmental struggle, environmental dynamism, environmental complexity and environmental munificence. 
All features of these dimensions (22 approved features) have a direct and significant relationship and an impact on organizational entrepreneurship in public hospitals in Iran. Meanwhile "uncertainty arising from technology feature" of environmental dynamism dimension is the most effective feature with $93 \%$ and "reducing services benefit" of environment struggle dimension is the least effective feature with $76 \%$. Based on these results, the main hypothesis of the study- direct and significant relationship between features and dimensions affecting organizational entrepreneurship in organizational entrepreneurship in public hospitals of Iran- was confirmed.

\section{Discussion}

The findings indicated that the dimensions of munificence, dynamism, complexity and environmental struggle influence the organizational entrepreneurial in Iranian public hospitals. Each of these dimensions involves certain Features and structures that form these dimensions.

According to Results of this study Environmental Dynamism Features respectively include: Uncertainty arising from technology, Unpredictability, The rapid advancement of technology and equipment, Uncertainty of demand and sharp Market fluctuations, Increase in knowledge (R \& D), and the inconsistency of external environment. These factors are available in external environment of Iranian public hospitals and directly affect their organizational Entrepreneurship.

Environmental Munificence Features that in this research has been approved their impact on organizational Entrepreneurship in Iranian public hospitals are information access and resources access.

Environmental Complexity Features that exists in this research environment and affect their organizational Entrepreneurship respectively include: Changes in stakeholders' expectations, organizational frequency of enterprise components, and Changes in disease patterns.

Environmental Struggle Features that the present study has been confirmed respectively include Globalization, monopolistic market, costs Increase, investment areas, raw materials quality Changes, Increased competition, Demand reduction, high-risk opportunities, standards and regulations Changes and finally, Reduction of the service profit. These factors are available in the environment, have an impact on their organizational Entrepreneurship, and are considered a threat for these hospitals.

Market sharp fluctuations, increased knowledge, the rapid progress of technology and communication equipment and components are the environmental dynamism components facing public hospitals in Iran and is bothering them. These changes cause instability, uncertainty and unpredictability of the future. In this matter, Emeri and Trist [5] also believe that the environment is constantly changing and completing and may gradually evolve toward more swings. They also believe that gradually the dependence between organizations will be increased because of increasing environmental sources and Functional interactions with the environment increase the level of organization to more complexity and dynamic. Toffler ${ }^{[11]}$ studied advances and changes in technology and their impact on the environment. He interpreted that advancing in knowledge will result in technology development. According to him, knowledge is the driving force and technology supplier to the rapidly changing environment.

One of the results of this study is that, dynamism dimension is of higher importance than complexity dimension. This point is consistent with the results of the study of Aldrich ${ }^{[23]}$ Dess and Beard ${ }^{[27]}$ and Khandwalla ${ }^{[30]}$. They believe that Dynamism compare to complexity refers to the variability of organization workplace. So, in formulating business strategies, the dynamism dimension is more important than the coherence or complexity.

One of the results of this study is to approve effect of components of environment complexity dimension that is change in diseases pattern, frequency of enterprise components, and change in stakeholders' expectations on organizational 
entrepreneurship of public hospitals in Iran. These factors affect the inside and outside of them. Therefore this Hospitals need to plan for their survival and prepare to deal with them. In so doing, the researchers such as Teopako ${ }^{[52]}$, lane and MaxField ${ }^{[53]}$ Chae and Hill ${ }^{[54]}$ and chakravarthy ${ }^{[55]}$ claim that factors such as customers, suppliers, and technology and policy makers form this complexity. Since hospitals have to consider so many components within and outside their business and industry field and in effective competition; range of complexity of competitors, suppliers, and costumers relationship, with other environmental factors are increasing. Black and Farias ${ }^{[56]}$ also believe that understanding complexity will makes use of data for planning and forecasting more difficult. Therefore conner ${ }^{[53]}$, lane and MaxField ${ }^{[57]}$ and Merry ${ }^{[58]}$ believe that greater complexity will lead to more changes and the adaption to these changes will make the problem worse. Also, Downey, Hellriegel and Slocum ${ }^{[59]}$, claim that homogeneity or complexity is equal to the number of working environment components.

The Iranian public hospitals sometimes have access to information, resources and optimum markets and sometimes have difficulty in this issue. In both of these conditions moving toward entrepreneurship is provided. In this regard, Bettis ${ }^{[60]}$ believes that some companies attempted to various selections and tend to have market entry with more resources to balance the risk in this way. By contrast, Tashman ${ }^{[61]}$ believes that organizations that are able to operate in environments with more resources are better able achieve these markets and provide new products and services. In other words, in both conditions (low and resource abundance) can cause environmental innovation and entrepreneurial activity. The important things to know is that, resource scarcity and resource abundance have important roles in the formation of entrepreneurial activities.

The findings of present study approve that Changes in standards and regulations, increased competition, the monopoly of some services and activities, and increase in environmental costs are of uncontrollable environmental struggle components out of Iran's public hospitals environment. These factors are warnings that threaten these organizations. Innovation and entrepreneurial activities are the best tactics for dealing these factors. The study is in line with Covin and Slevin ${ }^{[14]}$, Khandwalla ${ }^{[27]}$ and Miller and Frisen ${ }^{[37]}$ that the degree of environmental struggle for the environment is considered a direct threat. A struggle which is formed by risky industry settings, intense competition, high-pressure business environment and relative lack of opportunities. On the Other hand friendly and Munificence environment refers to environmental capacity that allows growth and stability to the organization and provides opportunities for investment and marketing.

In matter of the results of this study, many scientists, including Khandwalla ${ }^{[27]}$, covin and covin ${ }^{[62]}$ and Morris ${ }^{[63]}$, found that factors such as high-risk opportunities, monopoly, intense competition and changes in environmental standards and regulations are in environment. In this regard, Khandwalla ${ }^{[27]}$ and covin and covin ${ }^{[62]}$ claimed that features in a turbulent environment are in risk taking, stress and seeking to dominate. Industry risk taking, severe competition and the relative lack of exploitable opportunities, include these environmental features.

Another Features that is of the environmental struggle dimension and its impact on Organizational entrepreneurship in Iranian Public hospitals in the present research has been confirmed, is the phenomenon of globalization. According to almost the whole research population, regarding the direct and indirect changes that this phenomenon causes in healthcare industry, it results in disassemble of some of equations and pre-determined plans. In this matter, Brahm ${ }^{[64]}$, Pitt and Morris ${ }^{[65]}$, Weber ${ }^{[66]}$, Bartlett and Ghoshal ${ }^{[67]}$, Pearce ${ }^{[68]}$, Porter ${ }^{[69]}$ and Zahra and Garvis ${ }^{[70]}$ also agree that one of the major causes of increase in environmental disturbances level is a factor in business globalization and more desire for organizations to compete in a particular business field. The Bartlett and Ghoshal ${ }^{[67]}$ and Noria and Garcia-Pont ${ }^{[71]}$ in the same direction, say globalization will remove the former competitive industry structure and balance. Pearce ${ }^{[68]}$ also tells that achieving strategic capabilities to face global competition requires efficiency on a global scale, learning in the global scope and broad responsive power.

Policy makers and the managers of healthcare sector in Iran, especially hospitals, should take the most advantage of this phenomenon as an opportunity to promote their organization by prediction, planning, and optimum utilizing it, and keep 
abreast with the global changes and developments. In this matter Zahra and Garvis ${ }^{[70]}$ also agree the globalization, creates a way for companies that utilize a variety of skills and strategies, take the Innovation as a special competitive advantage for their organizations and have always encouraged these activities to industry.

Regarding the results of the present study, the environmental dimensions and features avilable in external environments of Iranian public hospitals are all effective on organizational entrepreneurship of these hospitals and are in direct relation with them. Consequently, by recognition and appropriate utility of the opportunities the environment offers to these hospitals, one can keep abreast with the environmental changes, promote the abilities and services, and overcome the sharp fluctuations and changes of the market that is one of the duties of executives in these organizations. In this matter Mc Cleary ${ }^{[72]}$ believes that some factors have naturally developed new opportunities and suitable environment for entrepreneurial, such as entrepreneurial like development of new knowledge, changing tastes and client's demands, large changes in market structure and industry, aging population and improved processes, new challenges. Guo ${ }^{[73]}$ also agree that the current health care environment shows intense competition; Entrepreneurship managers have also responsibility for innovations, entrepreneurs to develop innovations, manage changes, investment in environmental resources and identify environmental opportunities to enhance organizational responsibility.

According to Results of this study, entrepreneurial action including Innovation, Pioneering, rebuilding and new risky actions that are the components of organizational entrepreneurship are those that can be applied in organizational entrepreneurship in public hospitals in Iran. Three factors are involved in the development of entrepreneurial activities in health care industry. These factors are predisposing factors, enabling factors and reinforcing factors. If individuals or organizations have these factors, they can enter into entrepreneurial activities. In fact, using these criteria such hospitals will be able, to evaluated themselves.

\section{Conclusion}

According to introduced model, selected environmental dimensions (environmental dynamism, environmental complexity, environmental munificence and environmental struggle) and those features, exists in the external environment of public hospitals of Iran and influences in organizational entrepreneurship of them. Therefore, the external environmental factors in public hospitals of Iran are ready to motivate and lead the hospitals into entrepreneurial actions.

\section{References}

[1] Najafbeigi R. Organization and Management. Second edition, Scientific Publication of Islamic Azad UniversityTehran, Iran. 2005; 121.

[2] Naman JL, Slevin DP. Entrepreneurship and the concept of fit: A model and empirical tests. Strategic Management Journal. 1993; 14: 137-153. http://dx.doi.org/10.1002/smj.4250140205

[3] Bettis RA, Hitt MA. The New Competitive Landscape. Strategic Management Journal. 1995; 16; 7-19. http://dx.doi.org/10.1002/smj.4250160915

[4] D'Aveni RA. Hypercompetition: Managing the Dynamics of Strategic Maneuvering.New York: Free Press. 1994.

[5] Emery FE, Trist EL. The Causal Texture of Organizational Environments, Human Relations. 1965; 18(Febmar): 21-32.

[6] Hamel G, Prahalad CK. Competing for the Future. Boston: Harvard University Press. 1994.

[7] McCann J, Selsky JW. Hyperturbulence and the emergence of Type 5 environments. Academy of Management Review. 1984; 9(3): 460-470.

[8] Sampler J. Redefining Industry Structure for the Information Age. Strategic Management Journal. 1998 ; 19 (4): $343-355$. http://dx.doi.org/10.1002/(SICI)1097-0266(199804)19:4<343::AID-SMJ975>3.0.CO;2-G

[9] Terreberry S. The evolution of organizational environments. Administrative Science Quarterly. 1968; 12(4): $590-613$. http://dx.doi.org/10.2307/2391535

[10] Thurow L. writing in Gibson, Rowan ed. (1997). Rethinking the future: business, principles, competition, control, leadership, markets and the world, Nicholas Brealey Publishing, London. 
[11] Toffler A. Future shock. New York: Bantam Books.1970.

[12] Shortell SM, Kaluzny AD. Organization theory and health services management. In: Essentials of health care management, S.M. Shortell and A.D. Kaluzny, (Eds).Albany, New York: Delmar Publishers. 1997; 1-33.

[13] Qaempanah MJ. Principles, concepts and different perspectives on entrepreneurship. The first congress of entrepreneurshipin in health sector, Ministry of health and medical education. Simaye- farhang, Tehran, Iran. 2001; 25-29.

[14] Covin JG, Slevin DP. Strategic management of small firms in hostile and benign environments. Strategic Management Journal. 1989; 10: 75-87. http://dx.doi.org/10.1002/smj.4250100107

[15] Miller D, Friesen P. Strategy-making and environment: The third link. Strategic Management Journal. 1983; 4: $221-235$. http://dx.doi.org/10.1002/smj.4250040304

[16] Peters T. Thriving on Chaos: Handbook for a management revolution. London: Pan Books. 1987.

[17] Moqimi SM. Entrepreneurship in public organizations. Farandish, Tehran, Iran. 2005.

[18] Prokopenko J, Pavlin I. Entrepreneurship Development in Public enterprises. International Labor Organization. 1991.

[19] Miller D, Friesen P. Archetypes of strategy formulation. Management Science. 1978; 24: 921-933. http://dx.doi.org/10.1287/mnsc.24.9.921

[20] Child J. Organizational Structure, Environment, and Performance: The Role of Strategic Choice, Sociology. 1972; 63(January): $2-22$.

[21] Osborn NR, Hunt GJ. Environment and Organizational Effectiveness. Administrative Science Quarterly. 1974; 19(2): $231-246$. http://dx.doi.org/10.2307/2393892

[22] Randolph WA, Dess GG. The congruence perspective of organization design: a conceptual model and multivariate research approach. The Academy of Management Review. 1984; 9(1): 114.

[23] Aldrich HE. Organization and Environments. Englwood Cliff, NG: Prentice- Hall.1979.

[24] Castrogiovanni G. Environmental Munificence: A Theoretical Assessment, Academy of Management Review. 1991; 16(3): 542-65.

[25] Zahra SA. Entrepreneurship in Medium-Size Companies: Exploring the Effects of Ownership and Governance Systems, Journal of Management. 2000; September. http://dx.doi.org/10.1177/014920630002600509

[26] Khandwalla, Pradip N. Effectiveness of Management Styles, Organization and Administrative Sciences. 1976; 7(4).

[27] Khandwalla Pradip N. The Design of Organizations. New York: Harcourt. 1977.

[28] Starbuck W. Organizations and their environments. M. Dunnette (Ed.), Handbook of industricd crnd or cmixrtioncrl psychology. Chicago, Rand McNally. 1976; 1069-1 123.

[29] Haber S, Reichel A. The cumulative nature of the entrepreneurial process: The contribution of human capital, planning and environment resources to small venture performance. Journal of Business Venturing. 2007; 22: 119-145. http://dx.doi.org/10.1016/j.jbusvent.2005.09.005

[30] Dess G, Beard D. Dimensions of Organizational Task Environments. Administrative Science Quarterly. 1984; $29: 52-73$. http://dx.doi.org/10.2307/2393080

[31] Miller D. Strategy making and structure: Analysis and implications for performance. Academy of Management Journal. 1987; 30: 7-32. http://dx.doi.org/10.2307/255893

[32] Zahra SA. A conceptual model of entrepreneurship as firm behavior: A critique and extension. Entrepreneurship: Theory and Practice. 1993; 17(4): 5-21.

[33] Miller D. Relating Porter's business strategies to environment and structure: Analysis and performance implications. Academy of Management Journal. 1988; 31: 280-308. http://dx.doi.org/10.2307/256549

[34] Wiklund J, Shepherd D. Entrepreneurial orientation and small business performance: a configurational approach. Journal of Business Venturing. 2005; 20(1): 71-89. http://dx.doi.org/10.1016/j.jbusvent.2004.01.001

[35] Ayadurai S. An Insight into the Constraints faced by Women Entrepreneurs in a War-Torn Area: Case Study of the Northeast of Sri Lanka. Paper presented at the 50th World Conference of the International Council for Small Business (ICSB), Washington. 2004.

[36] Miller D. The correlates of entrepreneurship in three types of firms. Management Science. 1983; 29: 770-791. http://dx.doi.org/10.1287/mnsc.29.7.770

[37] Miller D, Friesen P. Innovation in conservative and entrepreneurial firms: Two models of strategic momentum. Strategic Management Journal. 1982; 3: 1-25. http://dx.doi.org/10.1002/smj.4250030102

[38] Momeni M, Faal-e-qayumi A. Statistical analysis with spss. Ketab Now. Tehran, Iran. 2011; 192-193.

[39] Lumpkin GT, Wales WJ, Ensley MD. Assessing the context for Corporate Entrepreneurship: The role of Entrepreneurial orientation, in M. Rice and T.G. Habbershon(eds), Praeger Perspectivs on Entrepreneurship, vol 3, Wesport, CA: Praeger publishers. 2006. 
[40] Zahra SA. Corporate Entrepreneurship and Growth cheltenhm:An Elgar Publishers Refererce Collection. 2005.

[41] Lumpkin G, Dess G. Clarifying the Entrepreneurial Orientation Construct and Llinking It to Performance. Academy of Management Review. 1996; 21(1): 135-72.

[42] Morris MH, Kuratko DF. Corporate Entrepreneurship. Harcourt College Publishers, Orlando, Florida. 2002.

[43] Antoncic B, Zorn O. The mediating role of corporate entrepreneurship in the organizational support-performance relationship: An empirical examination. Managing Global Transitions. 2004; 2(1): 5-14.

[44] Zahra SA. Predictors and financial outcomes of corporate entrepreneurship:an exploratory study. Journal of Business Venturing. 1991; 6: 259-285. http://dx.doi.org/10.1016/0883-9026(91)90019-A

[45] Zahra SA. Corporate Entrepreneurship and Financial Performance: The Case of Management Leveraged Buyouts. Journal of Business Venturing. 1995; 10(3): 225. http://dx.doi.org/10.1016/0883-9026(94)00024-O

[46] Zahra SA. Contextualizing theory building in entrepreneurship research. Journal of Business Venturing. 2007; 22: 443-452. http://dx.doi.org/10.1016/j.jbusvent.2006.04.007

[47] Antonic B, Hisrich RD. Clarifying the Entrepreneurship concept.Journal of small Business and Enterprise Development. 2003; 10(1): 7-24. http://dx.doi.org/10.1108/14626000310461187

[48] Antoncic B, Hisrich R. Intrapreneurship Construct refinement and cross-cultural validation. Journal of business venturing. 2001; 16(5): 495-527. http://dx.doi.org/10.1016/S0883-9026(99)00054-3

[49] Lumpkin GT. Do new entrant firms have an entrepreneurial orientation? Paper presented at theAcademy of Management Annual Meeting, San Diego, CA. 1998.

[50] Lumpkin GT \& Dess GG. Linking two dimensions of entrepreneurial orientation to firm performance: The moderating role of environment and industry life cycle. Journal of Business Venturing. 2001; 16(5): 429-451. http://dx.doi.org/10.1016/S0883-9026(00)00048-3

[51] Knight GA. Cross-cultural reliability and validity of a scale to measure firm entrepreneurial orientation. Journal of Business Venturing. 1997; 12(3): 213-225. http://dx.doi.org/10.1016/S0883-9026(96)00065-1

[52] Teopaco JL. Organizing for Marketing Orientation in Consumer Services Firms. Doctor of Business Administration thesis, Graduate School of Business Administration, Harvard University. 1993.

[53] Lane D, Maxfield R. Strategy under Complexity: Fostering Generative Relationships. Long Range Planning. 1996; $29: 215-231$. http://dx.doi.org/10.1016/0024-6301(96)00011-8

[54] Chae M, Hill JS. High versus low formality marketing planning in global industries determinants and consequences. Journal of Strategic Marketing. 1997; 5: 3-22. http://dx.doi.org/10.1080/096525497346848

[55] Chakravarthy B. A New Strategy Framework for Coping with Turbulence. Sloan Management Review. 1997; Winter: 69-82.

[56] Black J, Farias G. Dynamic Strategies: Emergent Journeys. Emergence. 2000; 2(1): 101-113. http://dx.doi.org/10.1207/S15327000EM0201_07

[57] Conner DR. Leading at the Edge of Chaos: How to Create the Nimble Organization. New York: John Wiley. 1998.

[58] Merry U. Coping with Uncertainty: Insights from the New Sciences of Chaos, Self- Organization, and Complexity. Westport: Praeger.1995.

[59] Downey HK, Hellriegel D, Slocum J. Environmental uncertainty: The construct and its application. Administrative Science Quarterly. 1975; 20: 613-629. http://dx.doi.org/10.2307/2392027

[60] Bettis RA .Performance differences in related and unrelated diversified firms. Strategic Management Journal. 1981; 2(4): $379-393$. http://dx.doi.org/10.1002/smj.4250020406

[61] Tushman ML, Anderson P. Technological Discontinuities and Organizational Environments. Administrative Science Quarterly. 1986; 31(3): 439-465. http://dx.doi.org/10.2307/2392832

[62] Covin JG, Covin T. Competitive aggressiveness, environmental context, and small firm performance. Entrepreneurship: Theory and Practice. 1990; 14(4): 35-50.

[63] Morris MH. Entrepreneurial intensity: Sustainable advantages for individuals, organisations and societies. Westport, ct: Quorum. 1998.

[64] Brahm R. National targeting policies, high-technology industries, and excessive competition. Strategic Management Journal. 1995; 16: 71-91. http://dx.doi.org/10.1002/smj.4250160918

[65] Pitt LF, Morris MH. When marketing and strategy become one. Journal of General Management. 1995; 21(2): 21-30.

[66] Weber M. Essays in Sociology. London: Routledge.1991.

[67] Bartlett CA, Ghoshal S. Managing Across Borders, The Trasnational Solution, Boston, Mass: Harvard Business School Press.1989.

[68] Pearce DW. Green Economics, Environmental Values. 1992; 1: 3-130. http://dx.doi.org/10.3197/096327192776680179 
[69] Porter ME. Changing Paterns of International Competition, California Management Review. 1986; 27: 9-40. http://dx.doi.org/10.2307/41165182

[70] Zahra SA, Garvis DM. International corporate ntrepreneurship and company performance: The moderating effect of international environmental hostility. Journal of Business Venturing. 2000; 15(5): 92-469.

[71] Noria and Garcia-Pont. Global Strategic Linkages and Industry Structure. Strategic Management Journal. 1991.

[72] McCleary KJ. Rivers PA,Schneller E.S. A Diagnostic Approach to Understanding Entrepreneurship in Health Care. Journal of Health \& Human Services Administration. 2006; Spring: 550-557. PMid:16583851

[73] Guo KL. Entrepreneurship management in health services: An integrativ model of health and human services administration. Journal of health and human services administration. Florida International University. 2006; 37(4): 505-530. 